\title{
What Skills Make a Salesperson Effective? An Exploratory Comparative Study among Car Sales Professionals
}

\author{
Nour El Houda Ben Amor ${ }^{1}$ \\ ${ }^{1}$ Assistant Professor, Marketing Department, College of Business Administration, King Saud University, Saudi \\ Arabia \\ Correspondence: Nour El Houda Ben Amor, Marketing Department, College of Business Administration, King \\ Saud University, Saudi Arabia.
}

Received: September 16, 2019

Accepted: October 9, $2019 \quad$ Online Published: October 22, 2019

doi:10.5539/ibr.v12n11p76

URL: https://doi.org/10.5539/ibr.v12n11p76

\begin{abstract}
This study explores important skills of an effective salesperson as well as their impacts in terms of performance from both sales managers and sales representatives perspectives. An exploratory research was conducted on a total of 58 car sales professionals that comprise 30 sales managers and 28 salespersons. A thematic analysis of interviews content indicates existence of both similarities and differences in skills perceptions among the two groups of sales professionals. Salespeople reveal that to be effective they should have communication and listening skills, knowledge possession, sales presentation skills, flexibility and adaptability, empathy, cooperative skills, honest and ethical behavior, and time management skills. Sales managers, on the other hand, highlighted the importance of two additional skills, namely the follow-up and technology skills. From the skills gap, the study suggests implications for academicians and practitioners.
\end{abstract}

Keywords: selling skills, sales performance, car sales professionals, effective salesperson, exploratory research

\section{Introduction}

Researching the skills of effective salespeople is crucial because they have great impact on hiring process, enhancing sales, developing, and expanding customer relationships. Salespersons' selling skills are identified as a determinant of salesperson performance (Churchill et al.1985; Churchill et al., 2000; Rentz et al., 2002). To face up an unstable business environment, sales departments should hire highly skilled salesperson as to ensure successful sales (Ingram et al., 2004 (a,b)). In such context, where extensive options and choices are offered to customers, sales force is a vital marketing tool. Skilled sales representatives efforts improve the company competitiveness by maximizing revenues from existing customers and through identifying new prospects (Futrell, 2006). Selling skills are categorized into four dimensions namely interpersonal skills, salesmanship skills, technical skills and marketing skills (Ahearne and Schillewaert, 2000; Rentz et al., 2002).

An expanded number of past research has developed and tested frameworks of salesperson performance and effectiveness (e.g. Walker et al., 1977; Weitz et al., 1986; Verbeke et al., 2011; Yang and Wu, 2014; Johlke, 2006; Shepherd et al. 1997; Galber et al., 2019). A recent qualitative study has provided a theoretical conceptualization of sales communication competence in B2B solution selling based on salespeople and sales communication educators opinions (Koponen et al., 2019). Another research has done a contemporary, systematic review of the academic literature on the characteristics of effective salespersons, the authors found that personal, organizational, co-worker, buyer and situational dimensions are responsible for increasing salespersons' performance (Herjanto et Franklin, 2019). However, noticeably a lack in the extant literature is found about a deep qualitative exploration of the skills of an effective sales representatives. In particular, there is no real attempts to explore skills' perception gaps within sales professionals. A dissimilarities understanding between managers and their sales subordinates on characteristics of effective salespersons will offer a guide for an efficient salesforce training content and smarter management strategy.

The purpose of this research is to reinforce understanding of salesperson effectiveness by exploring the skills of effective sales representatives and their effects from two perspectives. The present exploratory study examines the following questions: What do sales managers and salespeople consider the most important skills of an effective salesperson? What are the similarities or differences among the skills provided by the both sales professionals groups? And why these skills are important? 


\section{Literature Review}

\subsection{Sales Skills and Salesperson Performance Relation}

Sales performance is defined as "behavior evaluated in terms of its contribution to the goals of the organization" (Johnston and Marshall, 2006, p. 412). Performance includes two categories that conceptualize two areas of sales performance constructs, namely relationship performance and outcome-based performance. The first area focuses on behaviors that reinforce the relationship between buyers and sellers (Hunter and Perreault, 2006). The second one, represents measures of salesperson performance, especially quota achievement, growth in average billing size, increases in sales productivity, and overall revenue gain (Anderson and Oliver 1987; Cravens et al. 1993). The relational sales behaviors with customers are a "key aspect of externally oriented sales performance" (Hunter and Perreault 2006, p. 19). Consequently, a high-quality relationship sales performance brings a high outcome-based sales performance.

Sales Performance was largely discussed in the literature and strongly associated to the overall corporate performance. This concept is associated to the salespersons themselves rather than to factors not controllable by them, like market potential, intensity of competition or brand image (Churchill et al., 2000; Babakus et al., 1996). High-performing sales representatives add value for customers, influence future business intentions, discover and create business opportunities (Luthy, 2000; Gordon et al., 1997; Boles et al., 2000).

Numerous researches have examined the determinants of salesperson performance (e.g. Brown and Peterson, 1994; Churchill et al., 1985; Porter et al., 2003; Baldauf and Cravens, 1999; Piercy et al., 1997; McBane, 1995; Cravens et al., 1993; Ahearne and Schillewaert, 2000; Johlke, 2006). By Applying the classification scheme of sales performance antecedents developed by Walker et al. (1977), Churchill et al. (1985) extracted, through a meta-analysis, six predictive categories of salesperson's performance. Results indicate that when the average size of their association with salesperson performance is considered, the determinants were ordered as follows: role variables, sales skills (or skill levels), motivation, personal factors, aptitude, and organizational factors. Nevertheless when arranged according to real variation (i.e., not attributable to sampling error), the determinants were ranked: personal factors, sales skills, role variables, aptitude, motivation, and the organizational/environmental factors. The two classification showed that the sales skills were still the second most important determinant (Churchill et al., 1985). Substantively, the largest single determinant of salesperson performance found by the Churchill et al. (1985) are the selling skills. Nevertheless, few empirical studies has been done to either substantiate or refute this claim, and neither to operationalize the selling skills concept, until Rentz et al. (2002) proposed and tested a scale incorporating three sales skill-based dimensions: interpersonal, salesmanship, and technical skills. Ahearne and Schillewaert (2000) distinguished between the knowledge related to technical aspect of products and the knowledge associated to marketing (e.g. consumer knowledge). Therefore, sales skills focus on individual's sales learned proficiency required to perform the necessary sales tasks. They integrate two primary areas, namely micro-skill stream including interpersonal skills, salesmanship skills, and technical skills (Rentz et al., 2002), as well as macro-skill stream referring to marketing skills (Ahearne and Schillewaert,2000).

This paper aims to explore the individual salesperson skills perceived as determinant of sales performance from sales professionals perspectives.

\subsection{Selling Skills Dimensions}

The micro-skill stream category discerns three types of skills discussed below.

The interpersonal skills refer to mental as well as communication algorithms used during social communications and interactions to attain definite effects and result. They are mandatory to cope with and resolve conflicts. The interpersonal skills' sub-dimensions are listening, empathy, optimism, and perceived observation skills (Churchill et al., 2000; Rentz et al., 2002; Ford et al., 1983). Past studies showed a significant and positive relationship between these four sub-dimensions and performance (Comer and Drollinger; 1999; Castleberry and Shepherd, 1993; Ramsey and Sohi, 1997, Shepherd et al., 1997; McBane, 1995; Philling and Eroglu,1994; Rich and Smith, 2000; Rapisarda, 2002).

The salesmanship skills represent skills in selling or skills in persuading people to buy, hence they are crucial in making sales presentation and close sale (Manning and Reece, 2004). The sub-dimensions of salesmanship skills are adaptability, negotiation and questioning, salesperson cues and communication style skills, and consultative selling (Rentz et al., 2002). Previous results demonstrated a positive association amongst these five salesmanship skills and sales force performance (Babakus et al., 1996; Goolsby et al., 1992; Schuster and Danes, 1986; Morgan and Stoltman, 1990; Stafford, 1996; Whittler, 1994; Williams and Spiro, 1985; Futrell, 
2006; Leigh and Summers, 2002).

The technical skills indicate the salespeople proficiency in providing information about design, specification, applications, and functions of the products or services (Churchill et al., 2000; Futrell, 2006). They are also manifested in behavior to keep abreast with the technological development of products and services (Behrman and Perreault, 1982). Researchers have identified that the use of technical knowledge induce a higher salesperson performance (Babakus et al., 1996; Cravens et al., 1993; Baldauf and Cravens, 2002).

Salespersons collect knowledge about the industry trends, the economic structure, customers' needs and competitive information(Baldauf and Cravens, 2002; Futrell, 2006). This behavior constitutes the sales representatives' marketing skills named macro-skill stream. The marketing skills indicate the level of understanding a salesperson has about the business in which they operate (Ahearne and Schillewaert, 2000; Manning and Reece, 2004; Futrell, 2006) and they are critical to performing well selling tasks (Churchill et al., 2000; Shoemaker and Johlke, 2002; Ingram et al., 2004 (a,b)).

\section{Research Methodology}

\subsection{Sample and Data Collection}

To explore the attributes of effective salespeople and to understand why those characteristics are important, the data were collected from a total of 58 car sales professionals through a focused in-depth interview process. The empirical investigation was conducted, within the period from March to May 2019. The interview were addressed to the 30 sales managers and 28 sales representatives. The investigation was done nearby 15 auto car dealers' Showrooms in Riyadh city, Saudi Arabia, where sales professionals represented 32 of brands car (Table1). Once the data gathering began, the interviews were transcribed and analyzed. Data saturation is the point when the information collected in interviews becomes redundant (Bogdan \& Biklen, 2006). Saturation was attained after thirty interviews for sales managers and twenty eight ones for salespersons. Ninety percent of sales representatives were male. More than half of these respondents (54 percent) were aged between 20 and 30 with 39 percent between the ages of 31 and 40 , and 7 percent between 41 and 50 . The largest number salespeople interviewees (64 percent) have an experience between 1 and 5 years with 25 percent between 6 and 10, 7 percent between 11 and 15, and 4 percent more than 16 years' experience. Only one sales manager was female. The greatest number of them (57 percent) were between the ages of 31 and 40 with 27 percent aged between 41 and 50, 10 percent between 20 and 30, and 6 percent between 51 and 60. Sales managers interviewees that have an experience between 1 and 5 years represent 23 percent, those are with 6 to 10 years account for 37 percent, and 40 percent possess more than 11 years' experience.

Table 1. Car dealership' names

\begin{tabular}{|c|c|}
\hline Auto car dealers & Car brands \\
\hline AL Jazirah Vehicles; Abdullatif Alissa Automotive; Juffali & Jeep; Dodge; Ram; Fiat; Alfa Romeo; Hyundai; Toyota; \\
Automotive;Wallan Hyundai; AljomaihCar Company; & Bmw; Cadillac; Gmc; Chevrelet; GCA Motor; Bentley; \\
Peugeot; KIA Motors; Porshe Centre; United Motors; Audi & Mercedes-Benz; Lamborghini; Pagni; Porsche; Ferrari; \\
(Samaco automotive); Abdul Latif Jameel Motor; BMW & Aston Martin; Bugatti; McLaren; Lexus; Rolls Royce; \\
(Mohamed YousufNaghi Motors);Seven car lounge; Nice & Nissan; Peugeot; Kia; Ford; Audi; Chrysler; Land-Rover; \\
car; Lexus. & Jaguar; Volkswagen. \\
\hline
\end{tabular}

\subsection{Procedure and Data Analysis}

All interviews were conducted in Saudi dialect, in order to let the participants freely express their ideas. They were gathered in written or audio form according to the interviewee approval. Each individual interview lasted for an average of 25 minutes and enclosed three main questions: What are the skills (attributes/characteristics) of an effective salesperson? How would you rank these skills if you were to order them from "highest" to "lowest importance"? And why these skills are important (consequences on individual or firm performance)?

Interviewer followed a specific structure of first asking respondents to identify five to eight characteristics of effective salesperson. Once those attributes were identified, interviewees were asked to rank the skills evoked in order of importance. The interviewer then interrogated each interlocutor about the importance of each attribute. Such procedure allows researcher to extract most important characteristics of an effective salesperson and to investigate the consequences resulting from possessing them. 
A Thematic Analysis (TA) was used to examine interviews' data collected. This qualitative descriptive approach is described as "a method for identifying, analyzing and reporting patterns (themes) within data" (Braun and Clarke, 2006). TA involves the search for and identification of common threads that extend across an entire interview or set of interviews (Bowen,2006). A theme refers to a logical and consistent integration of scattered pieces of data that constitute the findings (Sandelowski and Leeman, 2012). It captures something important about data, a group of repeating ideas, in relation to the research question, and represents some level of response pattern or meaning within the data set (Ryan and Bernard, 2003; Braun and Clarke, (2006, 2013)).

The transcribed interviews were content analyzed. The attributes (skills) identified were first termed using the expressions of the participants, then merged into major themes and labeled on the basis of the existing literature. The effective salesperson's skills were aggregated and then associated to consequences resulting from their possession. The frequency that respondents mentioned the attributes among interviews and their ranking, in term of importance by respondents, were considered to extract a list of salesperson's top skills.

\section{Discussion of Research Results}

Interpretation of the data generated interesting findings that identified the skills of an effective salesperson, as well as explored differences and similarities in perceptions between sales managers and salespeople. Significant skills extracted from data analysis and an example of their verbatim were summarized in the table2.

Table 2. Skills of an Effective Salesperson according Salespersons and Sales managers Perspectives

\begin{tabular}{|c|c|c|}
\hline & \multicolumn{2}{|c|}{ Example verbatim } \\
\hline Skills & Salespersons & Managers \\
\hline 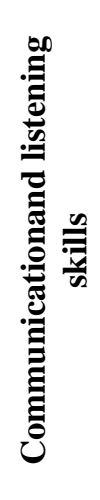 & $\begin{array}{l}\text { "I should be active listener, which means paying close } \\
\text { attention to the clients when he/she speaks." } \\
\text { "listen carefully to what the customers' saying is } \\
\text { mandatory" } \\
\text { "Communication is important to understand customer } \\
\text { needs" } \\
\text { "Without good communication skills I wouldn't know } \\
\text { what the customer is looking for" } \\
\text { "If I don't listen customer before sales presentation, } \\
\text { they will not trust on me and I will probably not close } \\
\text { the sale." }\end{array}$ & $\begin{array}{l}\text { "Sign language and body language are } \\
\text { important to communicate with customers" } \\
\text { "Communication skills are important to } \\
\text { persuade customers" } \\
\text { "Active listening increases sales, when you } \\
\text { listen well you will understand the customer } \\
\text { better" } \\
\text { "Salesperson's listening skills lead to } \\
\text { understand customer need" } \\
\text { "Through communication skills you will able } \\
\text { to make clients engaged and .... It helps build } \\
\text { trust with the clients." }\end{array}$ \\
\hline 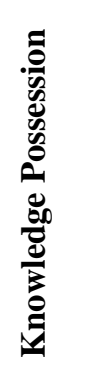 & $\begin{array}{l}\text { "Knowledge is important to build self- confidence and } \\
\text { important to the selling process." } \\
\text { "Product knowledge is important to deal objection, } \\
\text { communicate product's benefits, and gain customer's } \\
\text { trust." } \\
\text { "Knowledge about customers' needs allow successful } \\
\text { communication with customers" } \\
\text { "If we have knowledge about our competitors it will be } \\
\text { easier to beat them" }\end{array}$ & $\begin{array}{l}\text { "salesperson should have strong product } \\
\text { knowledge to persuade customers about it } \\
\text { benefits" } \\
\text { "Salesperson should collect information } \\
\text { about customers and their needs to } \\
\text { communicate easily with them" } \\
\text { "salesperson should have market knowledge } \\
\text { to adapt the sales presentation" }\end{array}$ \\
\hline 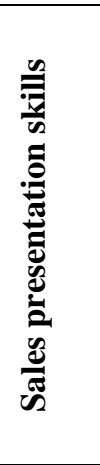 & $\begin{array}{l}\text { "It is important for salesperson to deal with objection." } \\
\text { "Persuasion and influencing skills, convincing ability } \\
\text { are mandatory for salespersons" } \\
\text { "it is important to have problem solving skills" } \\
\text { "The main task of the sales representative is to sell } \\
\text { goods, so the ability to close the sale is a must." } \\
\text { "Salesperson should have the ability to ask the right } \\
\text { question"" }\end{array}$ & $\begin{array}{l}\text { "Salesperson should use persuasion } \\
\text { techniques to convince customers" } \\
\text { "With negotiation skills, salesperson can go } \\
\text { smoothly to reach an agreement and close the } \\
\text { sale" } \\
\text { "The real challenge for salesperson is to close } \\
\text { sale with a mutual benefit for the } \\
\text { organization and the client" } \\
\text { "Salesperson should know when and how to } \\
\text { ask questions as well as how to overcome } \\
\text { objections" }\end{array}$ \\
\hline
\end{tabular}




\begin{tabular}{|c|c|c|}
\hline 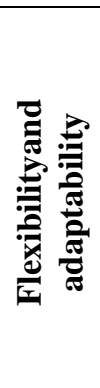 & $\begin{array}{l}\text { "salesperson should be able to adapt sales style from } \\
\text { situation to other" } \\
\text { " sales representative must have the willingness to } \\
\text { adopt new selling technique when needed to adapt the } \\
\text { sales presentation" } \\
\text { "Salesperson should be flexible" } \\
\text { "salesperson must have openness of mind, be open to } \\
\text { new ideas and experiences in order to adapt } \\
\text { communication with customers" }\end{array}$ & $\begin{array}{l}\text { "Salesperson should be able to personalize } \\
\text { their interaction with customers" } \\
\text { "Salesperson should be flexible and able to } \\
\text { cope with different customers personalities" } \\
\text { "Salesperson should have the ability to adapt } \\
\text { the sales presentation to the situations." } \\
\text { "Salesperson should be willing to learn, } \\
\text { develop and adopt new selling techniques" }\end{array}$ \\
\hline 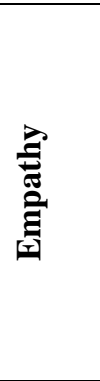 & $\begin{array}{l}\text { "Empathy and sensitivity to others are prerequisites to } \\
\text { great customer service." } \\
\text { "Putting itself in other's shoes and avoid prejudgment, } \\
\text { helps salesperson better understanding customers' } \\
\text { needs, enhance interaction and transmission of } \\
\text { product's advantages." } \\
\text { "When we express empathy toward customers, we try } \\
\text { to facilitate communication process and to inspire trust } \\
\text { in order to close sales." }\end{array}$ & $\begin{array}{l}\text { "Salesperson should be friendly in order that } \\
\text { customers feel comfortable and confident." } \\
\text { "Empathy helps the salesperson make a great } \\
\text { first impression, essential to close the sale" } \\
\text { "When the salesperson is charming a great } \\
\text { first impression comes and the customer will } \\
\text { be seduced, which affect positively customer } \\
\text { relationships as well as sales." }\end{array}$ \\
\hline 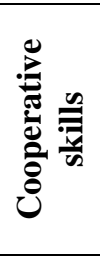 & $\begin{array}{l}\text { "Salesperson's social skills are important to attain a } \\
\text { good work performance" } \\
\text { "Salesperson should have proficiency in interacting } \\
\text { with people at all levels within an organization, ....This } \\
\text { skill lead to establish good relation others, good work } \\
\text { environment, less conflict and a great team work." }\end{array}$ & $\begin{array}{l}\text { "To be efficient Salesperson should have } \\
\text { teamwork skills " } \\
\text { " The most effective salespeople should have } \\
\text { social skills to deal with sales force team" }\end{array}$ \\
\hline 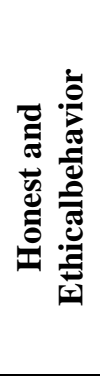 & $\begin{array}{l}\text { "salesperson should have respectful attitude towards all } \\
\text { customers" } \\
\text { "salesperson should have good behavior" } \\
\text { "salesperson should be honest. Not lying to our the } \\
\text { clients is important to establish trust." }\end{array}$ & $\begin{array}{l}\text { "salesperson should have good behaviour } \\
\text { with customers to build trust" } \\
\text { "Ethics in sales behaviours is crucial to avoid } \\
\text { negative reputation" } \\
\text { "If salesperson exaggerate about product } \\
\text { features, this will reflect negative image of } \\
\text { our brand." } \\
\text { "To close the sale, the salesperson must be } \\
\text { honest and build trust with clients" }\end{array}$ \\
\hline 离 & $\begin{array}{l}\text { "For salesperson, time management is a priority that } \\
\text { leads to high performance in sales" } \\
\text { "Effective time management is an essential part of } \\
\text { success in sales." } \\
\text { "The time allowed to each customer depends on the } \\
\text { number of customers in my responsibility, salesperson } \\
\text { should avoid keeping their clients waiting." }\end{array}$ & $\begin{array}{l}\text { "Successful salesperson should be able to } \\
\text { plan their schedule and manage their time" } \\
\text { "Good time management enable salesperson } \\
\text { to work smarter" } \\
\text { "In managing their time in a good way, } \\
\text { salespersons ensure high performance in } \\
\text { sales" }\end{array}$ \\
\hline 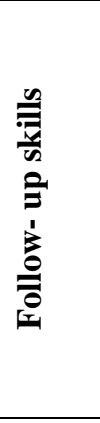 & & $\begin{array}{l}\text { "Salesperson's follow-up skills are crucial, it } \\
\text { is important to keep touch with customers via } \\
\text { phone call, email." } \\
\text { "Salesperson's follow-up skills increase } \\
\text { customer retention" } \\
\text { "Salesperson's ability to ensure after sales } \\
\text { services retain our relationship with the } \\
\text { clients. If salesperson didn't have this ability } \\
\text { no consumers relationships can be } \\
\text { maintained" }\end{array}$ \\
\hline
\end{tabular}




\begin{tabular}{|l|l|l|}
\hline & "Salesperson should use social media to \\
follow customers and gain knowledge about \\
new trends." \\
"Th most successful salespeople are \\
Tech-Savvy... They invest time to achieve \\
sales performance with lasted technology \\
tools." \\
"Salespersons should be socially active with \\
target buyers... It's essential to use \\
technology in prospecting gaining \\
knowledge and maintaining business \\
relations"
\end{tabular}

\subsection{Differences and Similarities in Skills}

The sales professionals interviewed expressed a strong agreement about eight skills that an effective salesperson need to have. However, opinions divergences between sales representatives and sales managers exist about skills' degree of importance as well as to their total number (Table3). On the one hand, salespersons and managers gave equivalent importance, in first position to communication and listening skills, in second one to knowledge possession, in third one to negotiation skills, questioning skills, deal with objection as well as closing skills, and in seventh one to honest and ethical behavior. On the other hand, they assign different importance levels to adaptability, empathy, human relation skills, and time management skills. Sales managers mentioned two skills ignored by salespersons, namely follow-up skills and technology skills, which increases the number of skills perceived as important for them to eleven. All the important skills of an effective salesperson extracted from the interviews were perceived as possessing consequences on the performance, both at the individual and organizational level (Table4).

Table 3. Ranking Skills of an Effective Salesperson according Salespersons and Sales Managers Perspectives

\begin{tabular}{ccc}
\hline & & Ranking* \\
\hline Skills & Salespersons & Managers \\
\hline Communication and listening skills & 1 & 1 \\
Knowledge Possession & 2 & 2 \\
Sales presentation skills & 3 & 3 \\
Flexibility and adaptability & 4 & 5 \\
Empathy & 5 & 8 \\
Cooperative skills & 6 & 4 \\
Honest and Ethical behavior & 7 & 7 \\
Time management skills & 8 & 6 \\
Follow up skill & n.l. & 7 \\
Technology skills & n.l. & 8 \\
\hline
\end{tabular}

Notes. *Skills with the same ranking reflect a tie in the number of times it was listed as important by respondent; n.l. $=$ not listed as a skill

Table 4. Skills' Consequences on Salesperson's Performance

\begin{tabular}{cl}
\hline Skills & \multicolumn{1}{c}{ Consequences } \\
\hline $\begin{array}{c}\text { Communication and listening } \\
\text { skills }\end{array}$ & Enhance customer knowledge, trust, persuasion power and hence closing sale. \\
Knowledge Possession & $\begin{array}{l}\text { Customer, product, competitors, and market knowledge enhance self-confidence as well as } \\
\text { facilitate selling process. }\end{array}$ \\
Sales presentation skills & Enhance sales \\
Flexibilityand adaptability & Effective sales presentation \\
Empathy & Facilitate communication \\
Cooperative skills & Improve teamwork and sales performance \\
Honest and Ethical behavior & Build trust and good brand image \\
Time management skills & Enhancing individual job performance \\
Follow up skill & Increase customer retention \\
Technology skills & Enhance knowledge possession and strengthen customer relationship \\
\hline
\end{tabular}




\subsubsection{Interpersonal Skills}

\section{Communication and Listening Skills}

Communication skills refer to the ability to show appropriate and effective verbal and nonverbal communication behavior in a certain context (Rubin, 1990). Listening in the sales context is defined as "the cognitive process of actively sensing, interpreting, evaluating and responding to verbal and nonverbal messages of present or potential customers" (Castleberry and Shepherd, 1993). Both managers and representatives considered communication and listening skills as the primary important skills of an effective salesperson. They attested that these skills lead to better understand customers, build trust relationship, enhance persuasion power, and increase closing the sale. This finding converge with past ones, where an effective listening was found as a valuable communication skill for a successful salespeople (Manna and Smith, 2004; Comer and Drollinger, 1999; Castleberry and Shepherd, 1993; Ramsey and Sohi , 1997; Shepherd et. al., 1997. A Good listening skills on behalf of the seller improve trust, relationship quality and the overall communication skills of salespersons (Ramsey and Sohi, 1997; Drollinger and Lucette, 2013). Equipped with an effective interpersonal listening ability, the sales representative acquires perceptions required for an adaptive selling behaviors, which is favorable for sales performance (Spiro and Weitz, 1990; Weitz et al., 1986). In fact, with a suitable communication competencies an effective interaction occurs, the salesperson can stimulate consumers' interest and persuade them to buy products and services (Omar, 2014; Omar and Mustaffa, 2012).

\section{Empathy}

Salesperson's empathy is considered as a personality trait (Wispe, 1987) and it is defined as " the perception on the part of a buyer that a significant other demonstrates that they both feel and think about that buyer's situation."(Spaulding and Plank, 2007; Plank et al., 1996). Sales representative empathy contributes toward the establishment of a trust level that affect the customer relationship, and consequently the sales performance (Grönroos 1990; Surprenant and Solomon, 1987; Comer and Drollinger, 1999; McBane, 1995; Pilling and Eroglu, 1994; Plank et. al., 1996; Deeter-Schmelz and Sojka (2003); Sojka and Deeter-Schmelz, (2002); Rapisarda, 2002; Spaulding and Plank, 2007; Limbu et al., 2016).As the previous studies have suggested, the respondents mentioned that empathy drives trust, thereby strengthen salesperson performance in selling process. Sales professionals in the research sample used the terms "charm", "friendly" and "sensitivity" to describe empathy. They affirmed that empathy on the part of the salesperson facilitates a two-way transmission of information, thus increases the salespersons understanding of needs and the consumers' understanding of product benefits. By improving understanding comes confidence, which in turn may lead to a feeling of trust in the representative's person and the product. Although an agreement that empathy is a crucial competence exist, the salespeople interviewed positioned it at a more high level of importance than sales managers. The disagreement on the given importance to empathy can be explained by the level of product experience. In fact, as customers acquire product experience an empathetic attitude become less important. Empathy has a significant effect on trust when customers are in the early stages of buying process (Coulter and Coulter, 2002).

\section{Honest and Ethical Behavior}

Sales professionals interviewed agreed on the importance of the honesty and ethical attitude as related to interactions between sales representatives and their customers. They highlighted the existence of a positive impact of salespeople's ethical behavior on brand image and on trust establishment. This result is consistent with antecedent researches, which confirmed that salesperson's honesty is regarded as a key determinant of buyers' assessment of the sellers' ethics (Babin et al., 2004)and that the perception of an ethical treatment by customer strengthen trust (Kwon and Suh 2004; Roman and Munuera, 2005).In addition, the product brand image and the corporate image perceived by customers are shaped by interactions experienced with the company salespersons (Andreassen and Lanseng, 1997). Hence, the sales force ethical behavior is considered as an antecedent of the brand image as well as of the corporate reputation (Fatima, 2018).

\section{Cooperative Skills}

Throughout the interviews analysis, sales managers and salespeople stressed on the importance of sales representative social skills that promote social interaction within the organization. Despite that managers conferred a greater importance to cooperative behavior than sales representatives, they completely agreed with them that team work skills are mandatory to create a more congenial work environment, reduce conflicts, and therefore reach a better salesperson performance. Accordingly, the salesperson cooperation was perceived as important for a good sales performance. This finding is supported by the sales literature. Cooperativeness was identified as salesperson personality trait linked to the interpersonal skills (Borg and Johnston, 2013). Cooperative behaviors of salespersons toward other salespeople working in the same organization were 
identified as crucial antecedent of the sales performance (Yilmaz and Hunt, 2001). Cooperation refers to the "willful contribution of individuals, groups, and so on, to the successful completion of common tasks and/or to the achievement of mutual objectives" (Anderson and Narus 1990; Deutsch 1949; Wagner, 1995). Within a cooperation, the sales force productivity increase since the sales representatives which are cooperative tend to share information, rely on division of labor, accept divergence in points of view, and express willing to assist and help each other (Tjosvold and Tsao, 1989; Laughlin, 1978).

\subsubsection{Salesmanship Skills}

\section{Sales Presentation Skills}

The sales presentation skills include skills that ensure an effective personal selling process and contribute to salesperson job performance (Marshall et al., 2003; Chonko et al., 1993; Peterson and Smith, 1995). The sales presentation represents a series of inter-related steps commonly used to interact with and persuade customers (Abdolvand and Farzaneh, 2013). Despite that the earlier researches have observed the use of sales presentation skills is broadly relevant and uniform across industries, products and sales situations (Moncrief, 1986), in the present study salespeople and sales managers conferred specific attention to some selling process' steps namely the negotiation, the questioning, the dealing with objections, and the closing. Focusing only on these five steps seems to come from a perception of their worth in cars sale. Moreover, sales professionals reported that these sales presentation skills are mandatory for sales success and they have conjointly positioned them third as important skills of an effective salesperson.

\section{Flexibility and Adaptability}

From the sales representatives opinion, the adaptability and flexibility hold the fourth place of important skills of an effective salesperson, while according sales managers perspective these skills occupy the fifth position. During the interviews, the sales professionals specified that the salespersons' ability to personalize selling techniques and communication style improve their flexibility in sales situations and with various consumers personalities. Hence, sales professionals established a clear linkage among adaptive sales behaviors and sales presentation effectiveness. This link was previously discussed in the literature and the favorable adaptive behavior effect on sales was supported. The sales representative ability to decrypt perceived information during customer encounter constitute a basis for adaptive selling behavior (Barton et al., 1986; Spiro and Weitz, 1990; Weitz et al., 1986). The adaptive selling indicates the customization level a salesperson is employing (Baldauf and Carvens, 2002). It is defined as "the salesperson's ability to alter her/is sales behavior when interacting with customers" (Weitz et al., 1986, p.175). An adaptive selling behavior has a positive impact on sales outcome performance and in turn on sales organization effectiveness (Barton et al., 1986; Babakus et al. 1996; Piercy et al.1999; Sujan et al. 1994; Boorom et al. 1998; Baldauf and Carvens, 2002).

\section{Follow-up Skill}

During the interviews, only the sales managers raised out the follow-up after sale as an important skill of an effective salesperson and they gave it the same importance as the honest and ethical behavior. In fact, as discussed above, honesty as well as ethic attitude create trust on salesperson-consumer relationship, so this relation must be maintained by a strong follow-up. Jobber and Lancaster (2009) affirmed that the follow-up is used essentially to provide reassurance that the purchase was the right one, hence it supports a long-term consumer relationship and the re-purchase intention. The phone calls and e-mails were the two techniques mentioned by the sales managers as efficient to keep lines of communication with clients, ensure after sale service and so enhance consumers retention. With advances in technology, websites and social media apps represent an interesting alternative to preserve an open dialogue with buyers. Accordingly, it is not surprising that sales managers claimed during their interviews that the salesperson should possess technology skills to perform efficiently they job tasks.

\subsubsection{Technical Skills}

\section{Technology Skills}

Even if sales managers ranked technology skills at the last position of importance, they affirmed that salespersons should be Tech-savvy to gain knowledge, follow customers, and prospecting. In addition, the sales managers linked the technology skills possession to sales performance and they described how technology fits into salespeople-customers interactions, especially through social media apps. Technology's influence on salespeople was largely discussed in the past studies and findings converge with the interviewees opinions. Sales technology literature focuses on sales-customer relationship management (CRM) (Ahearne, et al., 2004; Pass, et al., 2004; Plouffe, et al., 2004; Shoemaker, 2001; Zablah, et al., 2004) and sales automation technologies 
(Joneset al. 2002; Parthasarathy and Sohi, 1997; Pullig, et al. 2002; Schillewaert et al., 2005; Speier and Venkatesh, 2002). The information technology integration improve salespersons effectiveness and sales performance by enhancing customer service, building strong customer relationships, increasing the salespersons' adaptability, as well as their knowledge capital (Igbaria and Tan 1997,Duncan and Moriarty 1998, Jones et al., 2002). The sales technology orientation refers to the salesperson's tendency and analytical skills for using information technologies tools. A sales representative adopting this orientation will perform effective selling (Spiro and Weitz, 1990; Jones et al.,2002). Hence, the role of sales managers is to assess the overall fit between the sales process tasks and the sales technology tools used by salespersons for insuring that the sales force realizes performance returns from its investments in sales technology (Jones et al., 2002; Schillewaert et al., 2005). This sales managers' responsibility may explain why exclusively they emphasized that technology skills are important for effective salesperson.

\section{Knowledge Possession}

In the second place of importance, the sales managers and sales representative classified knowledge possession as an important skill of effective salespersons. Respondents defined knowledge possession in terms of product knowledge, customer knowledge, market knowledge, and competitors knowledge. They declared that salespeople knowledge develops a self-confidence facilitating the communication process and building trust with customers. Therefore, it is clear that sales professionals believe that salesperson knowledge possession should not be only restricted to technical information, but should also comprise a thorough understanding of micro and macro environment essential for sales effectiveness.

These findings correspond to the categorization of knowledge in the literature, where researchers distinguished the technical skills from those marketing(Churchill et al., 2000; Futrell, 2006; Behrman and Perreault, 1982; Ahearne and Schillewaert, 2000; Manning and Reece, 2004).The technical skills possession provides salespersons with an information expertise on products and services, as well as on technological advance in their field (Churchill et al., 2000; Futrell, 2006; Behrman and Perreault, 1982). Empirically, a positive correlation was found between technical knowledge and both salespeople outcome performance and sales organization effectiveness (Baldauf and Cravens, 2002; Babakus et al. 1996; Carvens et al. 1993; Piercy et al. 1999).The market knowledge competence refers to "the processes that generate and integrate market knowledge" and market knowledge is "the organized and structured information about the market" including knowledge about both actual and potential customers, as well as competitors ( $\mathrm{Li}$ and Calantone, 1998). The market knowledge process entails a number of behavioral activities that generate information about customers needs as well as competitors' products and strategies ( $\mathrm{Li}$ and Calantone, 1998). The market information acquisition, interpretation, and then integration on the organization system require an implementation of an operational CRM and a competitor information system (CIS), which are part of the marketing intelligence of an organization (Fletcher and Donaghy, 1993; Li and Calantone, 1998; Ahearne et al., 2004 ;Lies, 2019).Therefore, to build and possess market knowledge, the salespersons should acquire technology skills to easily adopt sales force automation (SFA) technology. SFA is a conduit of an organization's existing pool of intellectual capital to salespeople (Mariadoss, 2014) and hence a basis of their marketing skills. A strong consensus emerged from the literature concerning the positive impact of SFA use on salesperson effectiveness and efficiency (Huber, 1990; Tanner and Shannon, 2005; Ahearne et al., 2008).The knowledge possession either technical or marketingcontributes favorably to the salesperson performance. While, the technical knowledge expresses expertise level in product and service, the marketing one need technology skills. The link among marketing knowledge and technological competence was highlighted by sales mangers interviewed. This linkage was clearly cited by one sales manager in the following quotation: "It is essential to use technology in prospecting, gaining knowledge and maintaining business relations."

\subsubsection{Time Management Skills}

Although an agreement was found regarding the time management skills, considered as essential to an effective salesperson, there appears to be less entente as to the level of it importance. Salespersons positioned time management skills in the eighth position, while sales managers placed them in the sixth one. From the interviewed sales professionals' quotations, it raised that an effective time management is a prerequisite to success in sales because it allows them to work smarter. According the sales representatives and sales managers perspectives, the time management skills include competences in the management of the customer wait time and those related to the sales' activities that lead to high sales performance. This result is in coherence with literature where engaging time management behaviors is beneficial to the job performance of sales personnel (Berkowitz and Ginter, 1978; Feiertag, 1991; Friedman, 1993; Macan, 1994; Barling et al., 1996; Babakus et al. 1996 and Piercy et al. 1999). In the sales planning, the salesperson activities integrate the calls plan, the strategies selection 
plan, and the territory coverage plan (Baldauf and Carvens, 2002).

\subsection{Summary}

Throughout the content qualitative analysis, the sales professionals expressed a clear agreement about the existence of eight skills of an effective salesperson as well as on their consequences on sales performance. However, the skills' importance level was perceived differently by the two interviewees groups. From the most to least important, salespeople arranged skills as follows: communication and listening skills, knowledge possession, sales presentation skills, flexibility and adaptability, empathy, cooperative skills, honest and ethical behavior , and time management skills. Whereas sales managers ranked them as follows: communication and listening skills, knowledge possession, sales presentation skills, cooperative skills, flexibility and adaptability, time management skills, honest and ethical behavior, and empathy. Accordingly, the unanimity concerns three major skills that are communication and listening skills, knowledge possession and presentation skills. This is an interesting result since each of these skills represents a sub-dimension in the three selling skills' dimensions advanced by Rentz et al. (2002).

The communication and listening skills represent an interpersonal skills' sub-dimension. During the interviews, the sales professionals attested that the others interpersonal skills' sub-dimensions namely the empathy, the honest and ethical behavior, as well as the cooperative skills improve the communication and listening skills efficiency.

The knowledge possession is a technical skills' sub-dimension. Sales representatives and sales managers declared that this sub-dimension refers to the products technical information and the environment knowledge. Only the sales mangers indicated that technology skills represent a second sub-dimension of technical skills and they constitutes basis of knowledge possession.

The sales presentation skills constitute a salesmanship skills' sub-dimension. Findings showed that respondents affirmed that the flexibility and adaptability are also a sub-dimension of salesmanship skills that enhance salesperson efficiency during the sales presentation's steps. Solely sales managers added the follow-up as a third sub-dimension of salesmanship skills. They highlighted its importance in maintaining strong customer relationship, especially after achieving the sales presentation steps.

The time management skills does not appear in the selling skills' categorization advanced by Rentz et al. (2002). Nevertheless, the salespeople and the sales managers interviewed emphasized their importance for an effective sales representative.

\section{Research Implications and Limitations}

As highlighted throughout outcomes discussion, similarities exist on perception of eight important skills of an effective salesperson. Nevertheless, differences also are present. Contrary to the salespersons, the sales managers mentioned two additional skills during the interviews. They perceived the follow-up skill and the technology skills as crucial for sales presentation and knowledge possession, respectively. According to both perspectives of sales managers and sales representatives, the skills of an effective salesperson, the main connections between them, and their impact on sales performance are schematically presented in Figure1. 


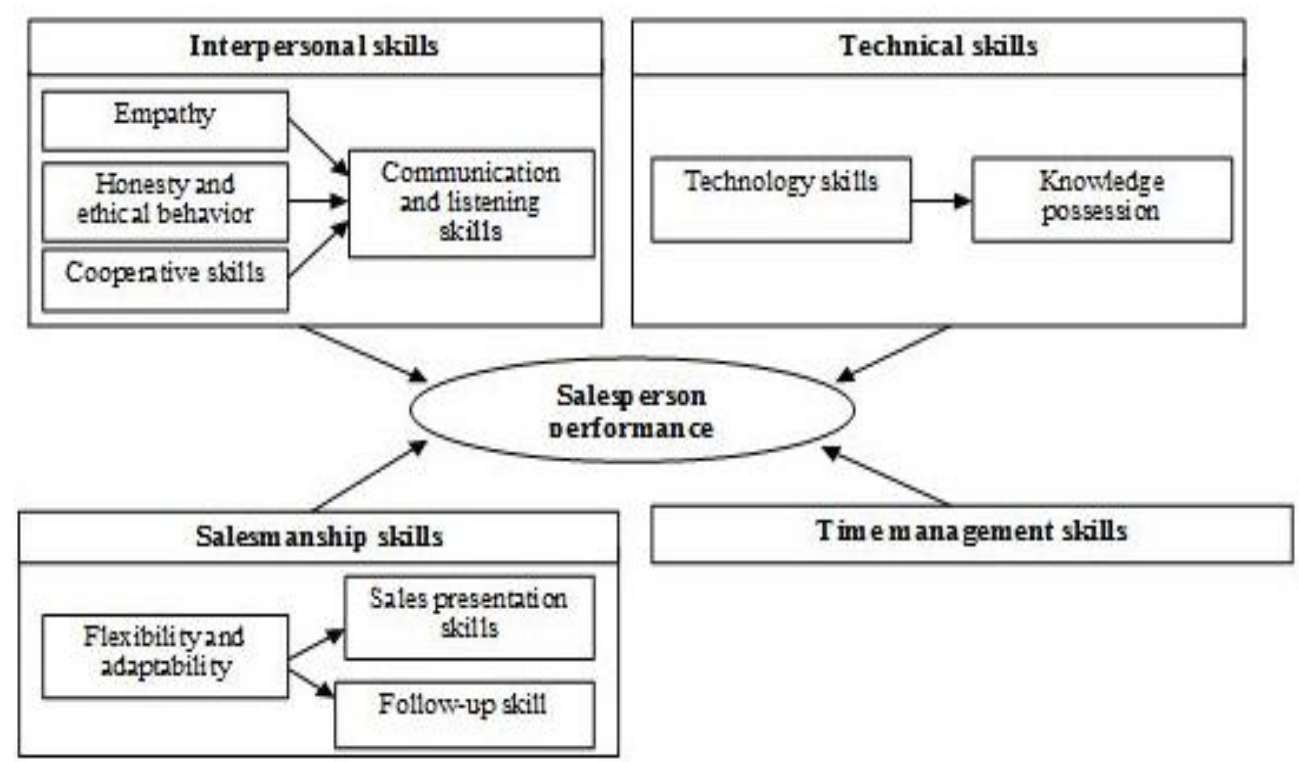

Figure 1. The impact of an effective salesperson's skills on the sales performance

The key contribution of this study is the identification of a set of salesperson skills that are important for research and practice given that they originated from the perceptions of sales professionals themselves. Both sales representative and sales manager points of view are important to consider, especially in their differences. No one's of the two perspectives is more accurate or correct than the other, contrariwise, they are complementary and bring contributions for academics as well as practitioners.

\subsection{Implications for Research}

The exploratory aspect of the investigation offers possible pathways for future research. First of all, the opportunity to examine the developed framework validity by a confirmatory analysis so as to provide evidence of the nature of the relationships among the skills identified and their direct or indirect consequences on sales performance. Future research would thus need to operationalize the skills extracted and examine the possible interactions that might exist between them.

In light of findings' differences between sales managers and sales representatives, both in term of number of skills as well as their level of importance, coming researches should explore more fully why these dissimilarities exist.

Given the consumer is as a part of the selling process, it would also be interesting to explore customers' points of view about the skills required for an effective salesperson. This will allow building a more comprehensive model, integrating both the sales professionals and consumers perspectives.

In addition, this research extend the selling skills concept operationalization. The time management skills emerged as a fourth selling skills dimension in addition to the three Rentz' et al (2002) dimensions namely, interpersonal skills, salesmanship skills, and technical skills.

The cooperative skills were identified by interviewers as an interpersonal skills sub-dimension, hence the five-item scale of Rentz et al. (2002), conceived for measuring interpersonal skills, should be revisited. The dimensions related to the salesperson's sociability and extroversion, namely collaborative, cooperative, emotional, supportive, warm, as well as emotional were identified as highly important sub-dimensions of interpersonal skills (Ambady et al., 2006). Consequently, a review of the selling skills concept dimensionality constitute an imminent research area.

Finally, future studies are called to investigate the importance of others determinants of salespeople's performance, that are motivation, role variables, personal factors, aptitude, and organizational/ environmental factors. Furthermore, the effects of possible moderators variables should be considered. As example, previous studies showed that the customer type and the product type affect the relation between determinants of 
salespeople's performance and sales performance (Churchill et al., 1985).

\subsection{Implications for Practice}

The study findings contribute to establishing a more best future management practices. This paper provides sales organizations, particularly in car industry, with a sales force training program guidelines. Results suggest that globally the sales managers and salespeople agree on eight skills affecting salesperson effectiveness. However, differences in points of view exist. The importance level of some skills and the significance of the follow-up after sale as well as of the technology skills are subjects of disagreement that should be emphasized in sales representatives training programs and management strategies conception.

In the digital era, the technology increases the speed and breadth of knowledge turnover, enhance trust, facilitate buyer-seller relationships and thus affect positively the sales process (Bruce and al., 1997). So it is surprising that salespeople did not mention technology skills as important for their work effectiveness. Unfortunately, some sales organizations are not aware of opportunities that technological innovation can offer and others encounter issues in technology implementation. One of the organizational barriers to technology adoption is salespersons' attitudes toward the use of computer technology applications in their job (Bruce and al., 1997). As consequence, an establishment of a sales automation-tools training program and a continual sales managers support will help salespeople to adopt technology(Jones et al., 2002; Pullig et al., 2002; Ahearne et al., 2005).

Andzulis et al. (2012) affirmed that despite their prominence impact in the sales process efficiency, the sales follow-up and customer service are frequently overlooked. A finding confirmed by the present research, where salespersons not mentioned the follow-up in their interviews. On the contrary, the sales managers considered the follow-up as important. Accordingly, they should build an efficient follow-up strategy and assist salespeople in it implementation. E-mails, calls, web site online forms, customer-facing social networking forums or groups and social media can be used to maintain a proactive on customers relationship management.

\subsection{Limitations}

This study, however, has some limitations which must be acknowledged. Foremost, the exploratory aspect of the investigation and the convenience sample of sales managers and sales representatives means the results are not generalizable. Future research may test the framework identified according a quantitative method. Subsequent studies might also investigate effect of the industry type, product type, and consumer type effects on the skills' perception of an effective salesperson.

\section{Acknowledgments}

This research project was supported by a grant from the Research Center for the Humanities, Deanship of Scientific Research, King Saud University.

\section{References}

Abdolvand, M. A., \& Farzaneh, S. (2013). Impact of Sales Experience and Training on Sales Presentation Skills between Industrial Salespersons. Research Journal of Applied Sciences, Engineering and Technology, 5(8), 2661-2670. https://doi.org/10.19026/rjaset.5.4712

Ahearne, M., \& Schillewaert, N. (2000). The effect of information technology on salesperson performance. Working Paper of E-business Research Center. Pennsylvania University.

Ahearne, M., Jelinek, R., \& Rapp, A. (2005). Moving beyond the direct effect of SFA adoption on salesperson performance: Training and support as key moderating factors. Industrial Marketing Management, 34, 379-388. https://doi.org/10.1016/j.indmarman.2004.09.020

Ahearne, M., Jones, E., Rapp, R., \& Mathieu, J. (2008). High Touch Through High Tech: The Impact of Salesperson Technology Usage on Sales Performance via Mediating Mechanisms. Management Science, 54(4), 671-685. https://doi.org/10.1287/mnsc.1070.0783

Ahearne, M., Narasimhan S., \& Luke W. (2004). Effect of Technology on Sales Performance: Progressing from Technology to Technology Usage and Consequences. Journal of Personal Selling \& Sales Management, 24(4), 297-310.

Ambady, N., Krabbenhoft, M. A., \& Hogan D. (2006). The 30-Sec Sale: Using Thin-Slice Judgments to Evaluate Sales Effectiveness. Journal of Consumer Psychology, 16(1), 4-13. https://doi.org/10.1207/s15327663jcp1601_2

Anderson, E., \& Oliver, R. L. (1987). Perspectives on Behavior-Based Versus Outcome-Based Sales Control Systems. Journal of Marketing, 51, 76-88. https://doi.org/10.1177/002224298705100407 
Anderson, J. C., \& Narus J. A. (1990). A Model of Distributor Firm and Manufacturer Firm Working Partnerships. Journal of Marketing, 54(1), 42-58. https://doi.org/10.1177/002224299005400103

Andreassen, W. T., \& Lanseng, E. (1997). The principal's and agents' contribution to customer loyalty within an integrated service distribution channel. European Journal of Marketing, 31(7), 487-503. https://doi.org/10.1108/03090569710176637

Andzulis, J. M., Panagopoulos, N. G., \& Rapp A., (2012). A Review of Social Media and Implications for the Sales Process. Journal of Personal Selling \& Sales Management, 32(3), 305-316. https://doi.org/10.2753/PSS0885-3134320302

Babakus, E., Cravens D. W., Kent, G., Ingram, T. N., \& LaForge, R. W. W. (1996). Investigating the Relationships Among Sales, Management Control, Sales Territory Design, Salesperson Performance, and Sales Organizational Effectiveness. International Journal of Research in Marketing, 13, 345-363. https://doi.org/10.1016/S0167-8116(96)00016-X

Babin, B. J., Griffin, M., \& Boles, J. S. (2004). Buyer reactions to ethical beliefs in the retail environment. Journal of Business Research, 57(10), 1155-1163. https://doi.org/10.1016/S0148-2963(02)00329-6

Baldauf, A., \& Cravens, D. W. (1999). Improving the Effectiveness of Field Sales Organizations: A European Perspective. Industrial Marketing Management, 28(1), 63-72. https://doi.org/10.1016/S0019-8501(98)00023-6

Baldauf, A., \& Cravens, D. W. (2002). The effect of moderators on the salesperson behavior performance and salesperson outcome performance and sales organization effectiveness relationships. European Journal of Marketing, 36(11/12), 1367-1388. https://doi.org/10.1108/03090560210445227

Barling, J., Kelloway, E. K., \& Cheung, D. (1996). Time Management and Achievement Striving Interact to Predict Car Sales Performance. Journal of Applied Psychology, 81(6), 821-826. https://doi.org/10.1037/0021-9010.81.6.821

Barton A. W., Harish S., \& Mita, S. (1986). Knowledge, Motivation, and Adaptive Behavior: A Framework for Improving Selling Effectiveness, Journal of Marketing, 50(4), 174-191. https://doi.org/10.1177/002224298605000404

Behrman, D. N., \& Perreault, W. D. (1982). Measuring the Performance of Industrial Salespersons. Journal of Business Research, 10, 355-370. https://doi.org/10.1016/0148-2963(82)90039-X

Berkowitz, E. N., \& Ginter, J. L. (1978). Time management in sales managers. Industrial Marketing Management, 7, 250-256. https://doi.org/10.1016/0019-8501(78)90043-3

Bogdan, R. C., \& Biklen, S. K. (2006). Qualitative research for education: An introductory to theory and methods. (5th ed.). Needham Heights, MA: Allyn and Bacon.

Boles, J., Brashear, T., Bellenger, D., \& Barksdale, H. (2000). Relationship selling behaviors: antecedents and relationship with performance. Journal of Business \& Industrial Marketing, 15(2-3), 141-153. https://doi.org/10.1108/08858620010316840

Boorom, L. M., Goolsby, J. R., \& Ramsey, R. P. (1998). Relational communication traits and their effect on adaptiveness and sales performance. Journal of the Academy of Marketing Science, 26(16), 16-30. https://doi.org/10.1177/0092070398261003

Borg, S. W., \& Johnston, W. J. (2013). Journal of Personal Selling \& Sales Management, 33(1), 39-52. https://doi.org/10.2753/PSS0885-3134330104

Bowen, G. A. (2006). Grounded Theory and Sensitizing Concepts. International Journal of Qualitative Methods, 5(3), 12-23. https://doi.org/10.1177/160940690600500304

Braun, V., \& Clarke, V. (2006). Using thematic analysis in psychology. Qualitative Research in Psychology, 3, 77-101. https://doi.org/10.1191/1478088706qp063oa

Braun, V., \& Clarke, V. (2013). Successful qualitative research: A practical guide for beginners. Thousand Oaks, CA: Sage.

Brown, S. R., \& Peterson, R. A. (1994). The effect of effort on sales performance and job satisfaction. Journal of Marketing, 58, 70-80. https://doi.org/10.1177/002224299405800206

Carvens, D. W., Ingram, T. N., LaForge, R. W., \& Young, C. E. (1993). Behavior-based and outcome-based salesforce control system. Journal of Marketing, 57, 47-59. https://doi.org/10.1177/002224299305700404 
Castleberry, S. B., \& Shepherd, C. D. (1993). Effective Interpersonal Listening and Personal Selling. Journal of Personal Selling \& Sales Management, 13, 35-49.

Chonko, L., Tanner, J., \& Weeks, W. (1993). Sales training: status and needs. Journal of Personal Selling and. Sales Management, 13, 81-86.

Churchill, G. A., Ford, N. M., Hartley, S. W., \& Walker, O. C. (1985). The determinants of salesperson performance: A meta-analysis. Journal of Marketing Research, 22, 103-118. https://doi.org/10.1177/002224378502200201

Churchill, G. A., Ford, N. M., Walker, O. C, Johnston, M. W., \& Tanner, J. F. (2000). Sales Force Management. Boston, MA: Irwin Mc Graw-hill.

Comer, L., \& Drollinger, T. (1999). Active Empathetic Listening and Selling Success: A Conceptual Framework. Journal of Personal Selling \& Sales Management, 19, 15-30.

Coulter, K., \& Coulter, R. (2002). Determinants of trust in a service provider: the moderating role of length of relationship. Journal of Services Marketing, 16(1), 35-50. https://doi.org/10.1108/08876040210419406.

Deeter-Schmelz, D., \& Sojka, J. (2003). Developing effective salespeople: Exploring the link between emotional intelligence and sales performance. International Journal of Organizational Analysis, 11(3), 211-230. https://doi.org/10.1108/eb028972

Deutsch, M. (1949). A Theory of Cooperation and Competition. Human Relations, 2, 129-152. https://doi.org/10.1177/001872674900200204

Drollinger, B. T., \& Lucette, C. (2013). Salesperson's listening ability as an antecedent to relationship selling. Journal of Business \& Industrial Marketing, 28(1), 50-59. https://doi.org/10.1108/08858621311285714

Duncan, T., \& Moriarty, S. E. (1998). A communication-based marketing model for managing relationships. Journal of Marketing, 62, 1-13. https://doi.org/10.1177/002224299806200201

Fatima, Z. (2018). Exploring the consequences of ethical behaviour: A review based approach. Management Dynamics, 18(2), 1-8.

Feiertag, H. (1991). Wasted time is a waste of sales opportunities. Hotel and Motel Management, 206, 206.

Fletcher, K., \& Donaghy, M. (1993). The Role of Competitor Information Systems. Marketing Intelligence \& Planning, 11(7), 4-18. https://doi.org/10.1108/02634509310051533

Ford, N. M., Walker, O. C. J., \& Churchill, G. A. J. (1983). Research perspectives on the performance of salespeople: Selected readings. Cambridge: Marketing Science Institute.

Friedman, S. A. (1993). Managing time is first step to success. National Underwriter, 97(9), 1.

Futrell, C. M. (2006). Fundamental of Selling: Customer for Life Through Services (9th Ed.). McGraw-Hill Irwin: New York.

Gabler, C. B., Vieira, V. A., Senra, K. B., \& Agnihotri, R. (2019). Measuring and testing the impact of interpersonal mentalizing skills on retail sales performance. Journal of Personal Selling \& Sales Management, 39(3), 222-237. https://doi.org/10.1080/08853134.2019.1578661

Goolsby, J., Lagrace, R., \& Boorom, M. (1992). Psychological Adaptiveness and Sales Performance. Journal of Personal Selling and Sales Management, 12, 51-66.

Gordon, G. L., Schoenbachler, D. D., Kaminski, P. F., \& Brouchous, K. A. (1997). New Product Development: Using the Salesforce to Identify Opportunities. Journal of Business \& Industrial Marketing, 12(1), 33-50. https://doi.org/10.1108/08858629710157922

Grönroos, C. (1990). Service Management and Marketing: Managing the Moments of Truth in Service Competition. Lexington Books, Lexington, MA.

Herjanto, H., \& Franklin, D. (2019). Investigating salesperson performance factors: A systematic review of the literature on the characteristics of effective salespersons. Australasian Marketing Journal, 27(2), 104-112. https://doi.org/10.1016/j.ausmj.2018.12.001

Hunter, G., \& Perreault, W. D. J. (2006). Sales Technology Orientation, Information Effectiveness, and Sales Performance. Journal of Personal Selling \& Sales Management, 26(2), 95-113. https://doi.org/10.2753/PSS0885-3134260201

Igbaria, M., \& Tan, M. (1997). The consequences of information technology acceptance on subsequent 
individual performance. Inform Management, 32, 113-122. https://doi.org/10.1016/S0378-7206(97)00006-2

Ingram, T. N., LaForge, R. W., Avila, R. A., Schwepker, J. C. H., \& Williams, M. R. (2004a). Sales Management: Analysis and Decision Making (5th ed.). Thomson South-Western: Ohio.

Ingram, T. N., LaForge, R. W., Ramon A., Schwepker, C. H., \& Williams, M. R. (2004b). Professional Selling: A Trust-Based Approach (4th ed.). Kindle Edition.

Johlke, M. C. (2006). Sales presentation skills and salesperson job performance. Journal of Business \& Industrial Marketing, 2l(5), 311-319. https://doi.org/10.1108/08858620610681614

Johnston, M. W., \& Marshall, G. W. (2006). Churchill/ Ford/Walker's Sales Force Management (8th ed.). Boston: McGraw-Hill/Irwin.

Jones, E., Sundaram, S., \& Chin, W. (2002). Factors leading to sales force automation use: A longitudinal analysis. Journal of Personal Selling and Sales Management, 22, 145-156.

Koponen, J., Julkunen, S., \& Asai, A. (2019). Sales communication competence in international B2B solution selling. Industrial Marketing Management. https://doi.org/10.1016/j.indmarman.2019.01.009

Kwon, I. G., \& Suh, T. (2004). Factors affecting the level of trust and commitment in supply chain relationships. Journal of Supply Chain Management, 4O(2), 4-14. https://doi.org/10.1111/j.1745-493X.2004.tb00165.x

Laughlin, P. R. (1978). Ability and Group Problem Solving. Journal of Research and Development in Education, $12,114-120$.

Leigh, T. W., \& Summers, J. O. (2002). An Initial Evaluation of Industrial Buyers' Impressions of Salesperson Nonverbal Cues. The Journal of Personal Selling \& Sales Management, 22, 41-53.

Li, T., \& Calantone, R. J. (1998). The Impact of Market Knowledge Competence on New Product Advantage: Conceptualization and Empirical Examination. Journal of Marketing, 62(4), 13-29. https://doi.org/10.2307/1252284

Lies, J. (2019). Marketing Intelligence and Big Data: Digital Marketing Techniques on their Way to Becoming Social Engineering Techniques in Marketing. International Journal of Interactive Multimedia and Artificial Intelligence, 5, 5. https://doi.org/10.9781/ijimai.2019.05.002

Limbu, Y., Jayachandran, C., Babin, B., \& Peterson, R. (2016). Empathy, nonverbal immediacy, and salesperson performance: the mediating role of adaptive selling behavior. Journal of Business \& Industrial Marketing, 31(5), 654-667. https://doi.org/10.1108/JBIM-03-2015-0048

Luthy, M. R. (2000). Preparing the Next Generation of Industrial Sales Representatives. Industrial Marketing Management, 29(3), 235-242. https://doi.org/10.1016/S0019-8501(99)00061-9

Macan, T. H. (1994). Time management: Test of a process model. Journal of Applied Psychology, 79, 381-391. https://doi.org/10.1037/0021-9010.79.3.381

Manna D. R., \& Smith A. D. (2004). Exploring the need for emotional intelligence and awareness among sales representatives. Marketing intelligence \& Planning, 22(1), 66-83. https://doi.org/10.1108/02634500410516922

Mariadoss, B. J., Milewicz, C., Lee, S., \& Sahaym, A. (2014). Salesperson competitive intelligence and performance: The role of product knowledge and sales force automation usage. Industrial Marketing Management, 43, 136-145. https://doi.org/10.1016/j.indmarman.2013.08.005

Marshall, W. G., Goebel, D. J., \& Moncrief, W. C. (2003). Hiring for success at the buyer-seller interface. Journal of Business Research, 56(4), 247-255. https://doi.org/10.1016/S0148-2963(02)00435-6

McBane, D. A. (1995). Empathy and the salesperson: A multidimensional perspective. Psychology and Marketing, 12, 349-370. https://doi.org/10.1002/mar.4220120409

Moncrief, W. (1986). Selling activity and sales position taxonomies for industrial salesforces. Journal of Marketing Research, 23, 261-270. https://doi.org/10.1177/002224378602300306

Morgan, F., \& Stoltman, J. (1990). Adaptive Selling-Insights from Social Cognition. Journal of Personal Selling and Sales Management, 10, 43-54.

Omar, N. (2014). Communication Competence during the Preparation Phase of the Direct Selling Communication Activities. Procedia - Social and Behavioral Sciences, 155, 228-235.

https://doi.org/10.1016/j.sbspro.2014.10.284 
Omar, N., \& Mustaffa, C. S. (2012). A development of a conceptual framework for studying communication competencies among direct sellers in Malaysia. Conference paper of the 12th Asia-Pacific Conference Association for Business Communication. Doshisha University, Kyoto.

Parthasarathy, M., \& Sohi, S. R. (1997). Salesforce Automation and the Adoption of Technological Innovations by Salespeople: Theory and Implications. Journal of Business and Industrial Marketing, 12(3-4), 196-208. https://doi.org/10.1108/08858629710188036

Pass, M. W., Evans, K. R., \& Schlacter, J. L. (2004). Sales Force Involvement in CRM Information Systems: Participation, Support, and Focus. Journal of Personal Selling \& Sales Management, 24(3), 229-234.

Peterson, R., \& Smith, B. (1995). An analysis of topical training areas perceived as desirable by sales managers. Journal of Applied Business Research, 11, 38-45. https://doi.org/10.19030/jabr.v11i2.5873

Philling, B. K., \& Eroglu, S. (1994). An Empirical Examination of the Impact of Salesperson Empathy and Professionalism and Merchandise Salability on Retail Buyers' Evaluations. The Journal of Personal Selling and Sales Management, 14, 45-58.

Piercy, N. F., Cravens, D. W., \& Morgan, N. A. (1999). Relationships between Sales Management Control, Territory Design, Salesforce Performance and Sales Organization Effectiveness. British Journal of Management, 10(2), 95-111. https://doi.org/10.1111/1467-8551.00113

Piercy, N. F., Cravens, D. W., \& Morgan, N. A. (1997). Sources of effectiveness in the business-to-business sales organization. Journal of Marketing Practice: Applied Marketing Science, 3(1), 45-71. https://doi.org/10.1108/EUM0000000004320

Plank, R. E., Ann, P. M., \& Reid, D. (1996). A Short Measure of Perceived Empathy. Psychological Reports, 79, 1219-1226. https://doi.org/10.2466/pr0.1996.79.3f.1219

Plouffe, C. R., Williams, B. C., \& Leigh, T. W. (2004). Who's on First? Stakeholder Differences in Customer Relationship Management and the Elusive Notion of 'Shared Understanding. Journal of Personal Selling \& Sales Management, 24(4), 323-338.

Porter, S. S., Wiener, J. L., \& Frankwick, G. L. (2003). The Moderating Effect of Selling Situation on the Adaptive Selling Strategy-Selling Effectiveness Relationship. Journal of Business Research, 56(4), 275-281. https://doi.org/10.1016/S0148-2963(02)00440-X

Pullig, C., Maxham, G. J. I, \& Hair, J. F. J. (2002). Salesforce Automation Systems: An Exploratory Examination of Organizational Factors Associated with Effective Implementation and Salesforce Productivity. Journal of Business Research, 55, 401-415. https://doi.org/10.1016/S0148-2963(00)00159-4

Ramsey, R. P., \& Sohi R. S. (1997). Listening to your customers: The impact of perceived salesperson listening behavior on relationship outcomes. Academy of Marketing Journal, 25, 127-137. https://doi.org/10.1007/BF02894348

Rapisarda, B. A. (2002). The Impact of Emotional Intelligence on Work Team Cohesiveness and Performance. International Journal of Organizational Analysis, 10(4), 363-379. https://doi.org/10.1108/eb028958

Rentz, J. O., Shepherd, C. D., Tashchian, A., Dabholkar, P. A., \& Ladd, R. T. (2002). A Measure of Selling Skill: Scale Development and Validation. Journal of Personal Selling \& Sales Management, 22(1), 13-21.

Rich, M. K., \& Smith, D. C. (2000). Determining Relationship Skills of Prospective Salesperson. Journal of Business and Industrial Marketing, 4, 242-259. https://doi.org/10.1108/08858620010335100

Roman, S., \& Munuera, J. L. (2005). Determinants and consequences of ethical behavior: An empirical study of salespeople. European Journal of Marketing, 39(5-6), 473-495.

Rubin, R. B. (1990). Communication competence. In G. M. Phillips, \& J. T. Wood (Eds.), Speech Communication: Essays to Commemorate the 75th Anniversary of the Speech Communication Association (pp. 94-129). Carbondale: Southern Illinois University Press.

Ryan, G. W., \& Bernard H. R. (2003). Techniques to identify themes. Field Methods, 15(1), 85-109. https://doi.org/10.1177/1525822X02239569

Sandelowski, M., \& Leeman J. (2012). Writing usable qualitative health research findings. Qualitative Health Research, 22, 1404-1413. https://doi.org/10.1177/1049732312450368

Schillewaert, N., Ahearne, M. J, Frambach, R. D., \& Moenaert, R. K. (2005). The Adoption of Information Technology in the Sales Force. Industrial Marketing Management, 34, 323-326. 
https://doi.org/10.1016/j.indmarman.2004.09.013

Schuster, C. P., \& Danes, J. E. (1986). Asking Questions: Some Characteristics of Successful Sales Encounters. The Journal of Personal Selling and Sales Management, 6, 17-27.

Shepherd, C. D., Stephen, B. C., \& Ridnour, R. E. (1997). Linking effective listening with salesperson performance: An exploratory investigation. Journal of Business and Industrial Marketing, 12(5), 315-322. https://doi.org/10.1108/08858629710183284

Shoemaker, M. E. (2001). A Framework for Examining IT Enabled Market Relationships. Journal of Personal Selling \& Sales Management, 21(2), 177-185.

Shoemaker, M. E., \& Johlke, M. C. (2002). An Examination of the Antecedents of a Crucial Selling Skill: Asking Questions, Journal of Managerial, 14(1), 118-131.

Sojka, J. Z., \& Deeter-Schmelz, D. R. (2002). Enhancing the emotional intelligence of salespeople. American Journal of Business, 17, 43-50. https://doi.org/10.1108/19355181200200004

Spaulding, D. G., \& Plank, R. E. (2007). Selling automobiles at retail: Is empathy important? The Marketing Management Journal, 17(2), 142-155.

Speier, C., \& Venkatesh, V. (2002). The Hidden Minefields in the Adoption of Sales Force Automation Technologies. Journal of Marketing, 66, 98-111. https://doi.org/10.1509/jmkg.66.3.98.18510

Spiro, R. L., \& Weitz, B. A. (1990). Adaptive Selling: Conceptualization, Measurement, and Nomological Validity. Journal of Marketing Research, 27(1), 61-69. https://doi.org/10.1177/002224379002700106

Stafford, T. F. (1996). Conscious and Unconscious Processing of Priming Cues in Selling Encounters. Journal of Personal Selling and Sales Management, 16, 37-44.

Sujan H., Weitz, B. A., \& Kumar N. (1994). Learning Orientation, Working Smart, and Effective Selling. Journal of Marketing, 58(3), 39-52. https://doi.org/10.1177/002224299405800303

Surprenant, C. F., \& Solomon, M. R. (1987). Prediction and Personalization in the Service Encounter. Journal of Marketing, 51, 86-96. https://doi.org/10.1177/002224298705100207

Tjosvold, D., \& Tsao, Y. (1989). Productive Organizational Collaboration: The Roles of Values and Cooperation. Journal of Organizational Behavior, 10(2), 189-195. https://doi.org/10.1002/job.4030100209

Verbeke, W., Dietz, B., \& Verwaal, E. (2011). Drivers of sales performance: a contemporary meta-analysis. Have salespeople become knowledge brokers? Journal of the Academy of Marketing Science, 39, 407-428. https://doi.org/10.1007/s11747-010-0211-8

Wagner, J. A. (1995). Studies of Individualism-Collectivism: Effects on Cooperation in Groups. Academy of Management Journal, 38(1), 152-172. https://doi.org/10.5465/256731

Walker, O. C. J., Churchill, J. A. J., \& Ford, N. M. (1977). Motivation and Performance in Industrial Selling: Present Knowledge and Needed Research. Journal of Marketing Research, 14, 156-168. https://doi.org/10.1177/002224377701400203

Weitz, B. A., Sujan, H., \& Sujan, M. (1986). Knowledge, motivation and adaptive behavior: a framework for improving selling effectiveness. Journal of Marketing, 50, 174-191. https://doi.org/10.1177/002224298605000404

Whittler, T. E. (1994). Eliciting Consumer Choice Heuristics: Sales Representatives' Persuasion Strategies. Journal of Personal Selling and Sales Management, 14, 41- 44.

Williams, K. C., \& Spiro, R. L. (1985). Communication Style in the Salesperson-customer Dyad. Journal of Marketing Research, 22, 434-442. https://doi.org/10.1177/002224378502200408

Wispe, L. (1987). History of the Concept of Empathy. In Eisenberg \& Strayer, J. (Eds.), Empathy and its Development (pp. 17-33). Cambridge GB: Cambridge University Press.

Yang, D. J., \& Wu, M. J. (2014). Does Customer Trust Play a Mediating Role Between Salesperson Competence and Performance? International Journal of Management, Economics and Social Sciences, 3(2), 100-121.

Yilmaz, C., \& Hunt, S. D. (2001). Salesperson Cooperation: The Influence of Relational, Task, Organizational, and Personal Factors. Journal of the Academy of Marketing Science, 29(4), 335-357. https://doi.org/10.1177/03079450094207

Zablah, A. R., Bellenger, D. N., \& Johnston, W. J. (2004). Customer Relationship Management Implementation 
Gaps. Journal of Personal Selling \& Sales Management, 24(4), 279-295.

\section{Copyrights}

Copyright for this article is retained by the author(s), with first publication rights granted to the journal.

This is an open-access article distributed under the terms and conditions of the Creative Commons Attribution license (http://creativecommons.org/licenses/by/4.0/). 